\title{
Weed Management in Sugarcane ${ }^{1}$
}

\author{
D. C. Odero and J. A. Dusky²
}

Sugarcane (Saccharum spp. interspecific hybrids) is an important crop cultivated on organic or muck soils in the Everglades Agricultural Area and surrounding sand or mineral soils in southern Florida. Successful weed control is essential for economical sugarcane production in Florida. Weeds can reduce sugarcane yields by competing for moisture, nutrients, and light during the growing season (Figure 1). Competition from fall panicum (Panicum dichotomiflorum) (Figure 1), the most prevalent and problematic annual grass weed species in Florida sugarcane, can result in up to $62 \%$ yield loss when adequate control measures are not taken (Odero et al. 2016). Several weed species also serve as alternate hosts for disease and insect pests. Weed control is most critical early in the season prior to sugarcane canopy closure over the row middles. Heavy weed infestations can also interfere with sugarcane harvest by adding unnecessary harvesting expenses. A weed that is allowed to mature and produce seed will multiply weed control problems by being a source of seed bank replenishment and re-infestation in subsequent years. Reduction of the weed seed bank using integrated weed management techniques is the most costeffective method for weed control in sugarcane. This article describes techniques that can be used by growers to make management decisions to help control weeds in sugarcane.
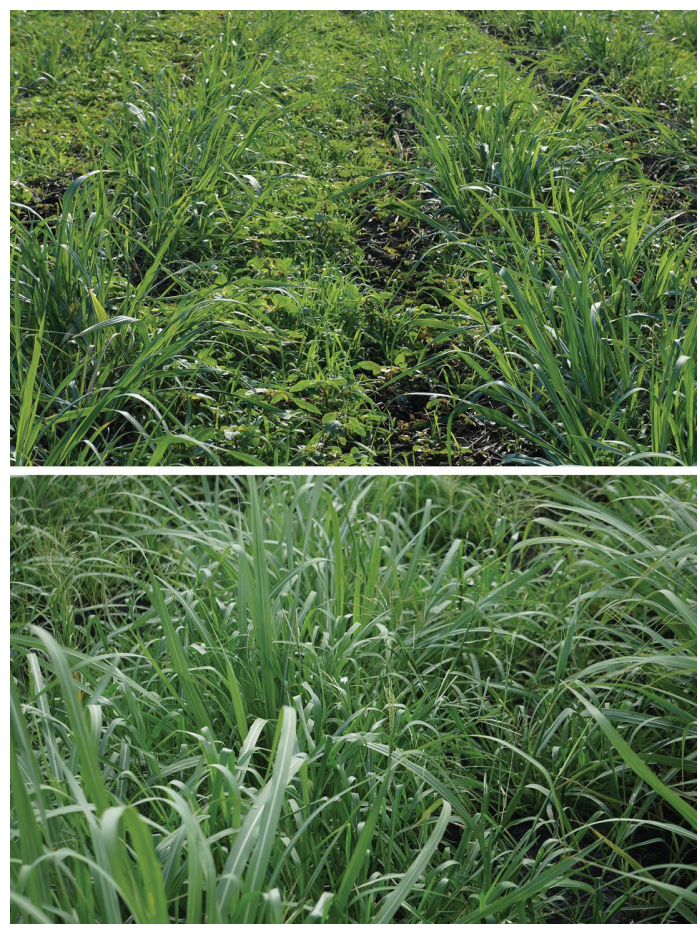

Figure 1. Sugarcane fields infested with broadleaf and grass weeds (top photo) and fall panicum (Panicum dichotomiflorum) (bottom photo).

Credits: Calvin Odero, UF/IFAS

1. This document is SS-AGR-09, one of a series of the Agronomy Department, UF/IFAS Extension. Original publication date August 2000. Revised November 2010 and July 2021. This publication is also a part of the Sugarcane Handbook, an electronic publication of the Agronomy Department. For more information, contact the editor of the Sugarcane Handbook, Hardev S. Sandhu (hsandhu@ufl.edu). Visit the EDIS website at https://edis.ifas.ufl. edu for the currently supported version of this publication.

2. D. C. Odero, associate professor, Agronomy Department, UF/IFAS Everglades Research and Education Center; and J. A. Dusky, professor emeritus, Horticultural Sciences Department; UF/IFAS Extension, Gainesville, FL 32611.

The use of trade names in this publication is solely for the purpose of providing specific information. UF/IFAS does not guarantee or warranty the products named, and references to them in this publication do not signify our approval to the exclusion of other products of suitable composition.

Use pesticides safely. Read and follow directions on the manufacturer's label.

The Institute of Food and Agricultural Sciences (IFAS) is an Equal Opportunity Institution authorized to provide research, educational information and other services

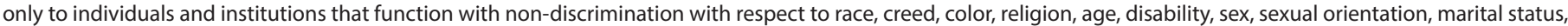
national origin, political opinions or affiliations. For more information on obtaining other UF/IFAS Extension publications, contact your county's UF/IFAS Extension office. U.S. Department of Agriculture, UF/IFAS Extension Service, University of Florida, IFAS, Florida A \& M University Cooperative Extension Program, and Boards of County Commissioners Cooperating. Nick T. Place, dean for UF/IFAS Extension. 


\section{Crop Rotation}

Crop rotation patterns will affect weed management of a sugarcane crop. Sugarcane in Florida is grown in rotation with leafy vegetables, green beans, sweet corn, rice, celery, cabbage, and radish. Rotation of sugarcane with these crops results in use of herbicides with different modes of action that help manage difficult-to-control weeds and mitigate herbicide resistance development. Weed management must be intensified in successive planting operations when rotations with the aforementioned crops are not possible. Successive planting occurs when fields are immediately replanted following termination of the final ratoon crop. Under successive planting management, weed populations are not severely reduced between crops and weed pressure will increase if adequate control measures are not implemented. Traditionally, the fallow period between final ratoon harvest and subsequent sugarcane planting has effectively been used to manage troublesome perennial weeds such as bermudagrass (Cynodon dactylon). This is accomplished primarily by a combination of mechanical cultivation and herbicide application. Flooding fallow fields also aids in weed control through the development of an anaerobic environment in which weed seed germination and seedling growth are inhibited. In addition, flooding organic soils during the fallow period improves soil health, prevents soil subsidence (Bhadha et al. 2018), and reduces infestation of wireworms (Melanotus communis) in plant cane (Cherry 2017). Wireworms cause significant economic damage to sugarcane. For more information, see EDIS publication ENY-665, Wireworms in Florida Sugarcane (https://edis.ifas.ufl.edu/publication/SC013).

\section{Crop Competition}

Crop competition for sunlight is one of the most important concepts utilized for effective weed control. A good stand of sugarcane that emerges rapidly and uniformly and forms a complete canopy that shades the row middles early in the season is very helpful in reducing weed competition. The loss of sugarcane stools in ratoon crops due to rodent, insect, or harvest damage will create open spaces in the sugarcane canopy in which weeds can proliferate. Therefore, a concentrated effort to maintain maximum sugarcane populations throughout all phases of production will benefit weed control efforts. Banding of fertilizer on furrows prior to sugarcane planting (Figure 2), rather than broadcasting, enhances sugarcane's competitiveness by enabling the crop to get to nutrients more quickly instead of weeds.

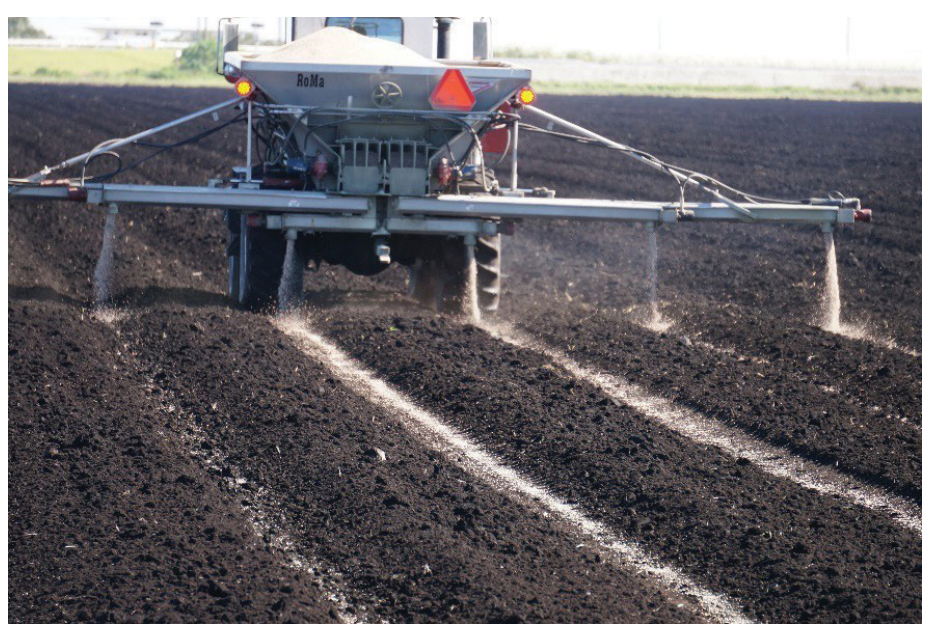

Figure 2. Banding fertilizer on furrows for sugarcane planting. Credits: Calvin Odero, UF/IFAS

\section{Cultivation}

Post-planting cultivation can be an economical means of suppressing weed growth (Figure 3 ). To ensure that the sugarcane plants have the early advantage in the competition for sunlight, a height differential must be established between cane plants and weeds. Preemergence (PRE) herbicides are the most effective in establishing this height differential. Only when the sugarcane plants are growing taller than competing weeds can mechanical cultivation be effective. However, cultivation when weeds are not present due to herbicide application or previous cultivations is not recommended. Cultivation when weeds are not present can encourage germination of additional weed seeds, and can remove the layer of herbicide present when soil-applied PRE herbicides are used. In ratoon crops, mechanical cultivators must be able to cut through surface debris from harvesting and thoroughly mix the soil (Figure 4).

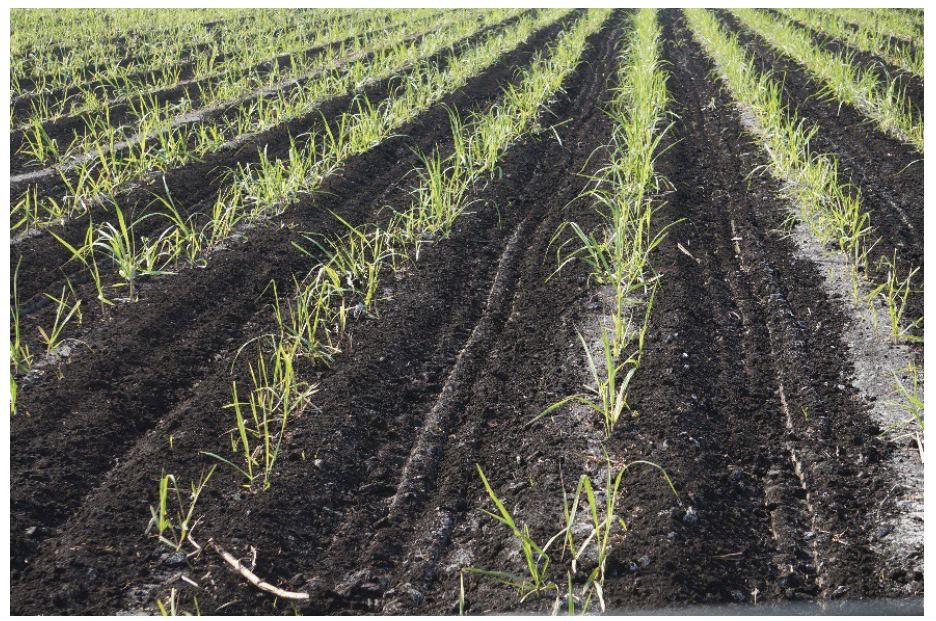

Figure 3. Post-planting inter-row cultivation in plant cane field. Credits: Calvin Odero, UF/IFAS 


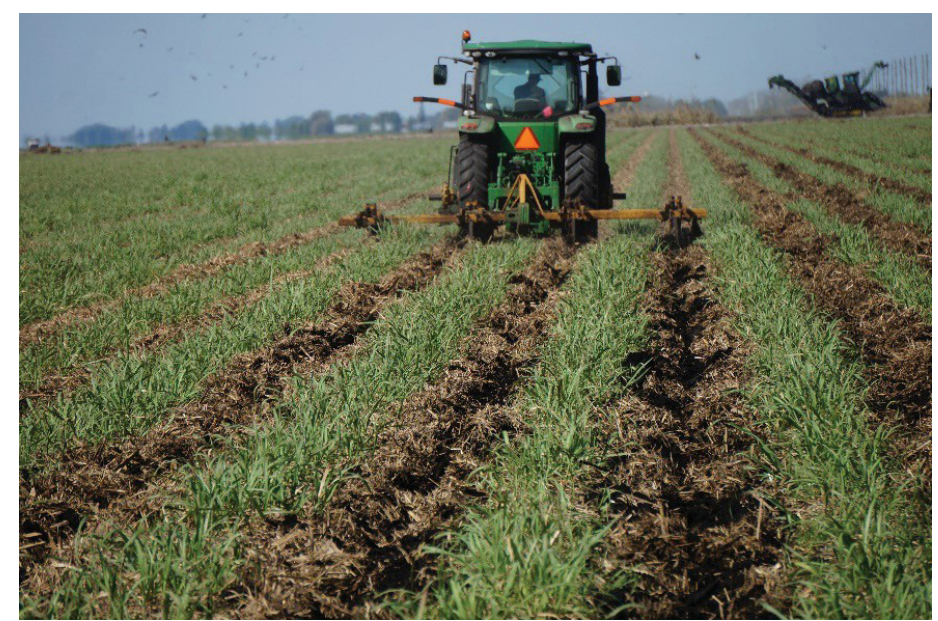

Figure 4. Mechanical inter-row cultivation in a ratoon cane field with surface debris.

Credits: Calvin Odero, UF/IFAS

\section{Field Sanitation}

Good field sanitation practices are important in minimizing introduction of weed seeds from field to field. Field sanitation practices must take place during the entire sugarcane crop cycle, rotational cropping sequence, and fallow period. Keeping field surroundings such as canals and ditch banks (Figure 5) free of weeds is important in eliminating sources of weed infestation. Cleaning farm equipment when moving from a field with a history of weed infestation to other fields is important in limiting introduction of weed seeds into fields with no prior infestation.

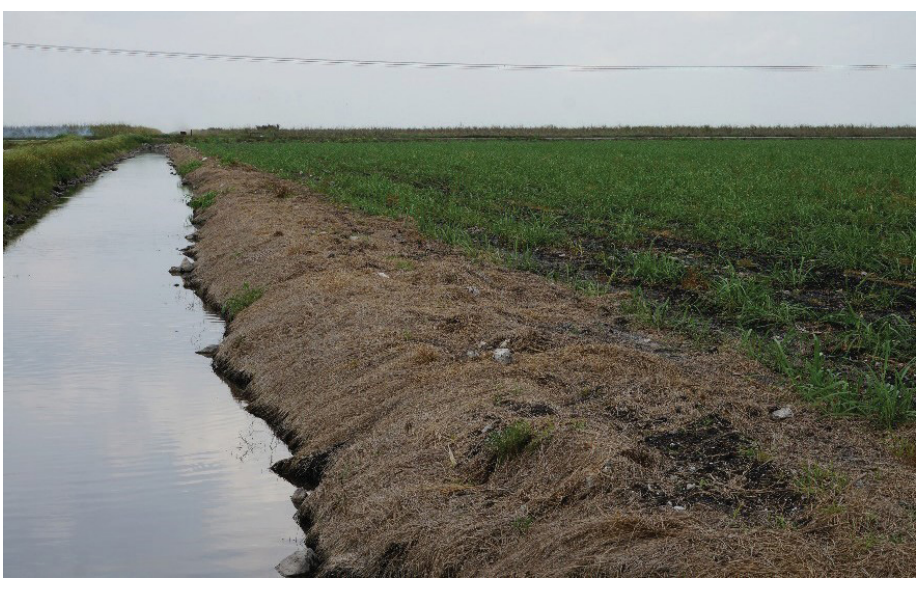

Figure 5. Dead weed debris along a ditch bank adjacent to a sugarcane field.

Credits: Calvin Odero, UF/IFAS

\section{Herbicides}

Herbicides can be useful and economical tools in sugarcane production (Table 1). They must be incorporated into an overall management plan to obtain their maximum benefit. It is important that sugarcane plants have the initial competitive advantage against weeds. PRE herbicide applications, in conjunction with mechanical cultivation, help to ensure the early season advantage. Directed or semi-directed postemergence (POST) herbicide applications can generally only be effective if the sugarcane is taller than the competing weeds. Accurate herbicide placement is crucial for banded or directed applications. High application speeds and rough fields can result in low application uniformity, particularly with banded applications. Speed must be limited if movement of the boom or drop nozzles results in excessive amounts of herbicide actually depositing in the untreated strip. Broadcast applications are generally less affected by these factors, since nozzle overlap helps ensure uniformity of herbicide placement. Proper timing of herbicide application with respect to the growth stage of the weeds is extremely critical. Normally, weeds should be treated when they are less than 4 to 8 inches in height because small weeds are easier to control than larger, more mature weeds (Figure 6). Always read the label for the proper time of application of each herbicide.

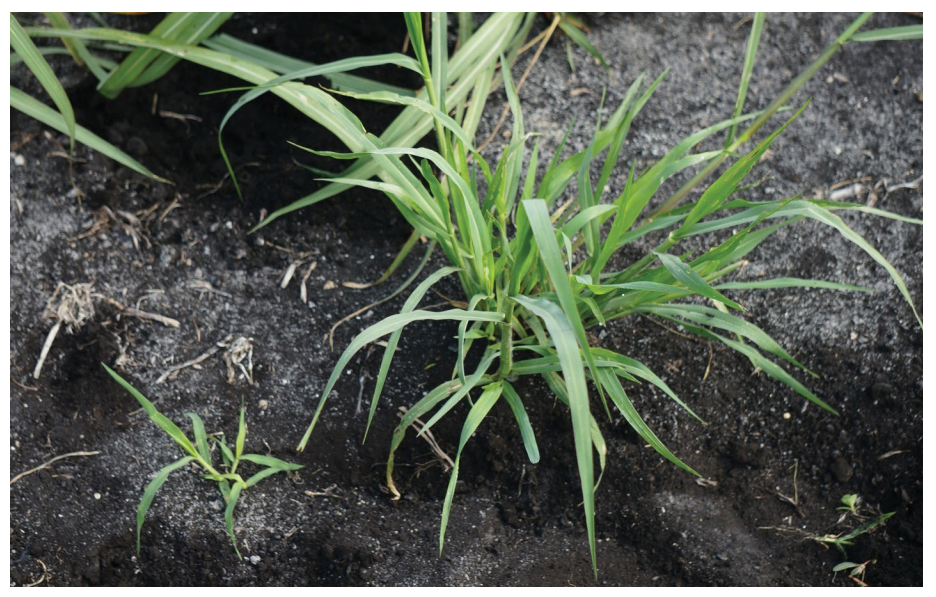

Figure 6. Small fall panicum (Panicum dichotomiflorum) seedling (on the left) is much easier to control than tillering a more mature plant (on the right).

Credits: Calvin Odero, UF/IFAS

The herbicides suggested in this publication are those that have performed well in UF/IFAS research. Herbicide users must read the label and follow all instructions and precautions carefully. Accurate calibration of application equipment is extremely important in providing effective weed control (Figure 7). For more information on the calibration of application equipment, see EDIS publication SS-

AGR-102, Calibration of Herbicide Applicators (https://edis. ifas.ufl.edu/publication/wg013). Each grower must evaluate the effectiveness and economic usefulness of herbicides for their particular situation. Initial use of these chemicals should be restricted to a limited acreage for familiarization. You are responsible for the performance of the chemicals you use. Herbicides, like any pesticide, should be handled with care. Store herbicides behind locked doors in the original containers with the label intact and separated from seed, fertilizers, and other pesticides. 

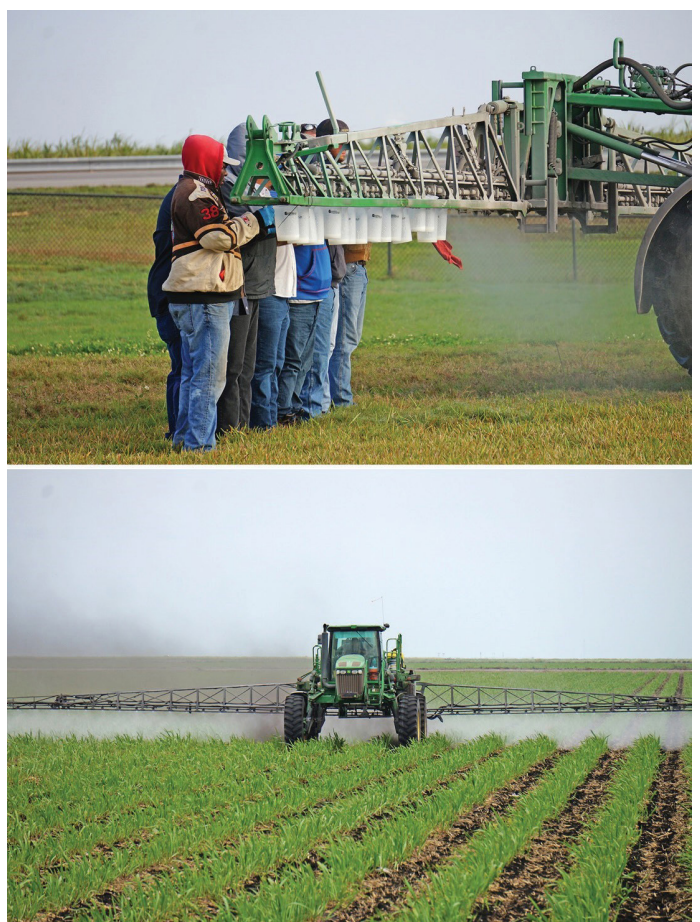

Figure 7. Sprayer calibration exercise (top photo) and broadcast herbicide application in sugarcane (bottom photo). Credits: Calvin Odero, UF/IFAS

\section{References}

Bhadha, J. H., R. Khatiwada, S. Galindo, N. Xu, and J.

Capasso. 2018. "Evidence of Soil Health Benefits of Flooded Rice Compared to Fallow Practice." Sustainable Agriculture Research 7:31-41.

Cherry, R. H. 2017. Wireworms in Florida Sugarcane. ENY665. Gainesville: University of Florida Institute of Food and Agricultural Sciences. https://edis.ifas.ufl.edu/publication/ SC013

Odero, D. C., M. Duchrow, and N. Havranek. 2016. "Critical Timing of Fall Panicum Removal (Panicum dichotomiflorum) in Sugarcane." Weed Technology30:13-20. 


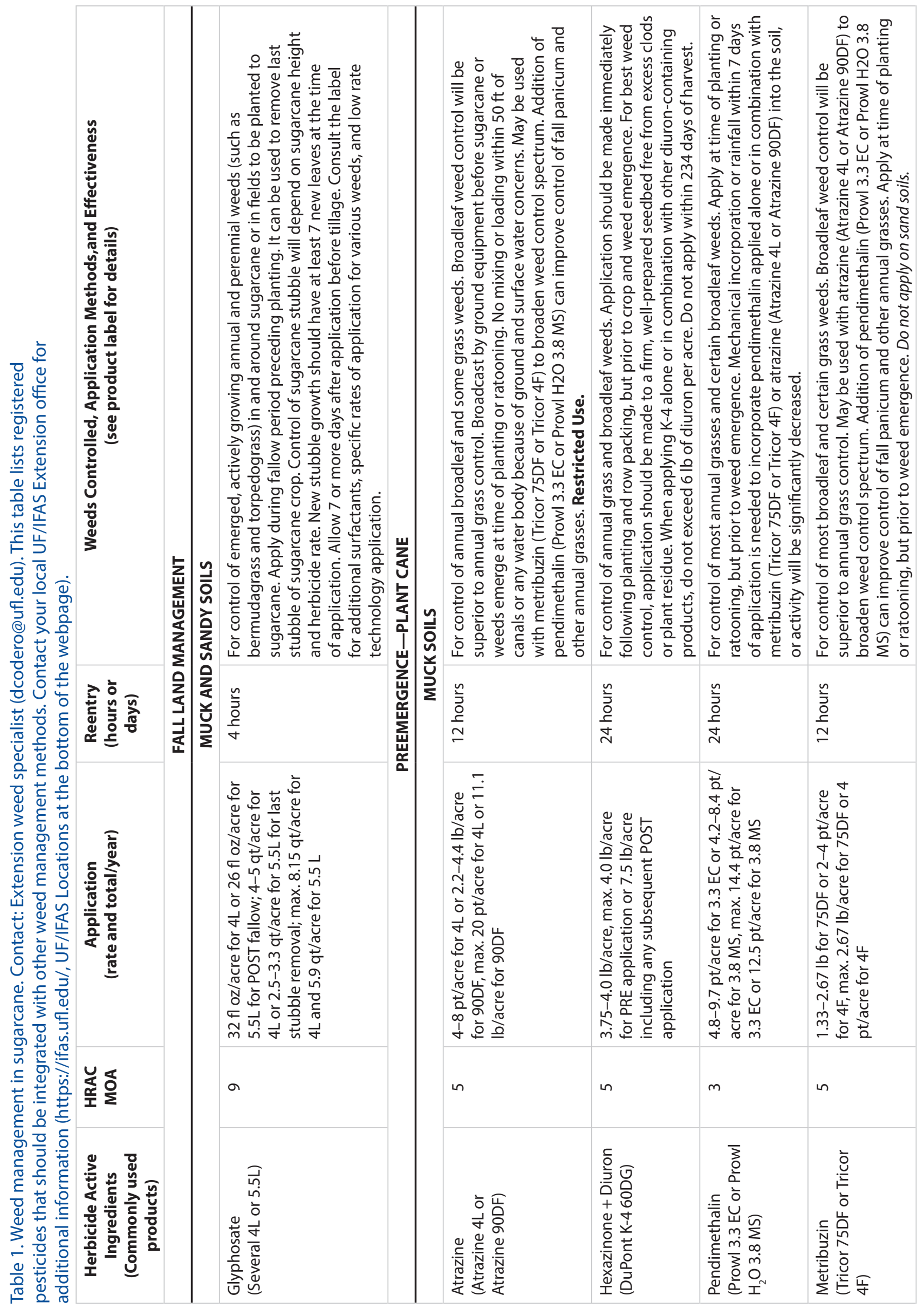




\begin{tabular}{|c|c|c|c|c|c|c|c|c|}
\hline 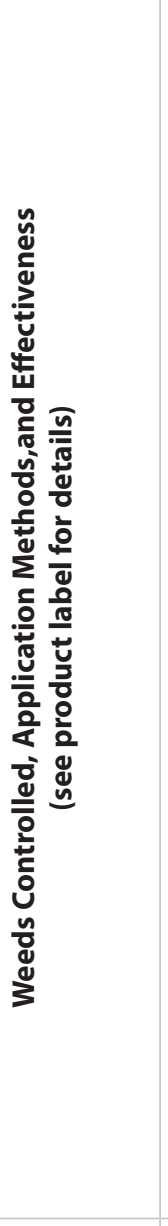 & 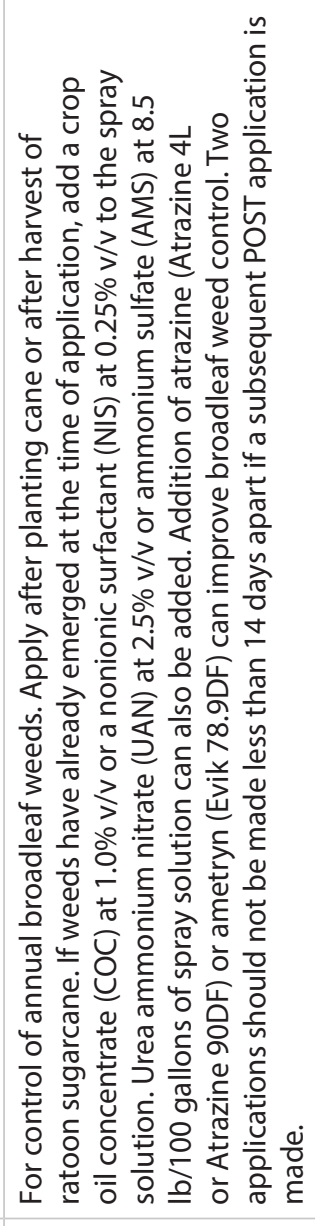 & 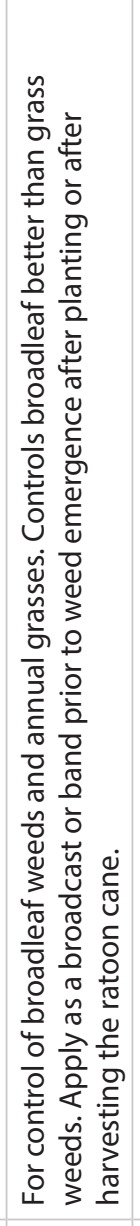 & 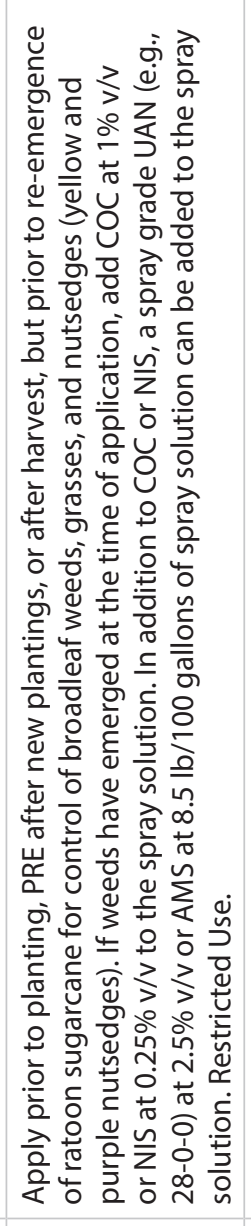 & 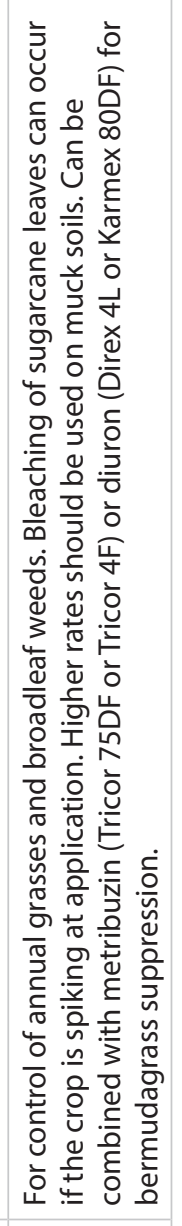 & 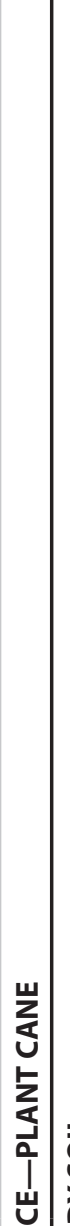 & 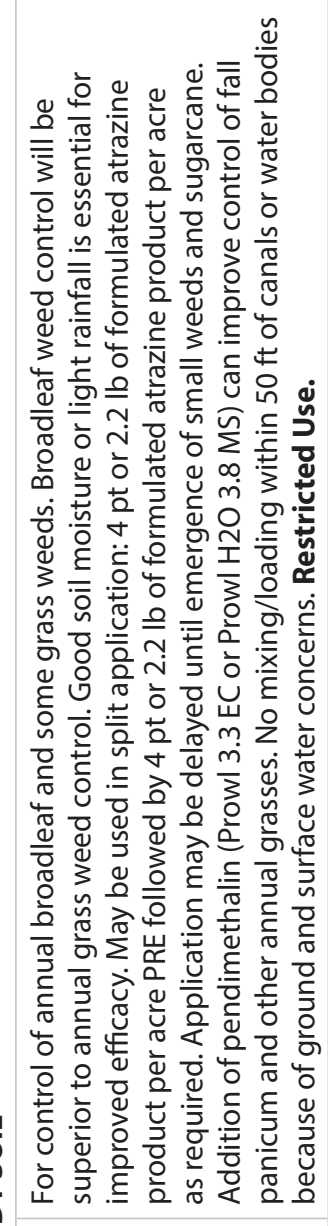 & 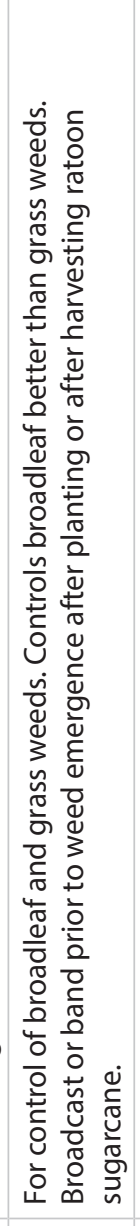 & 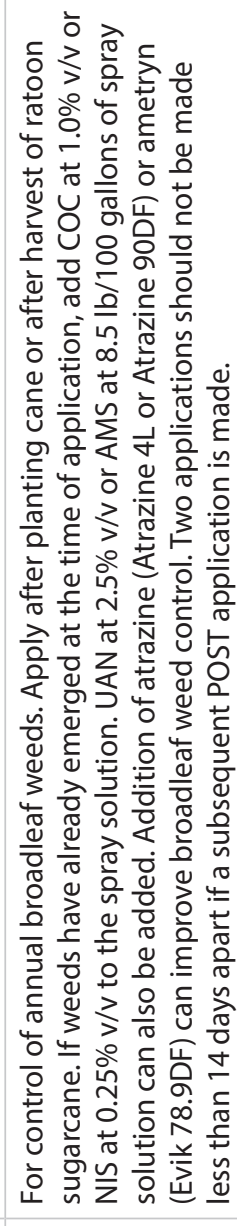 \\
\hline 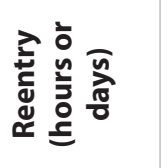 & 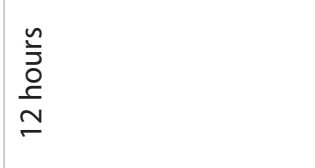 & 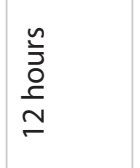 & 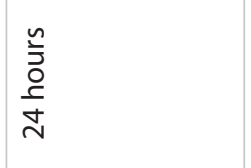 & 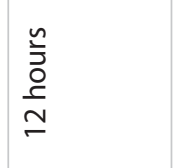 & 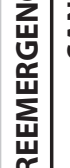 & 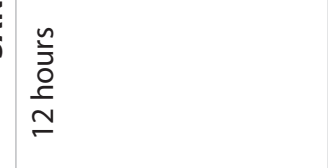 & 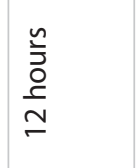 & 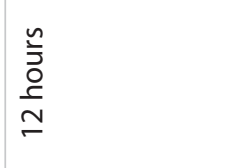 \\
\hline 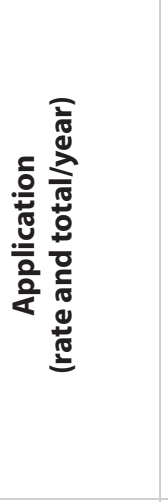 & 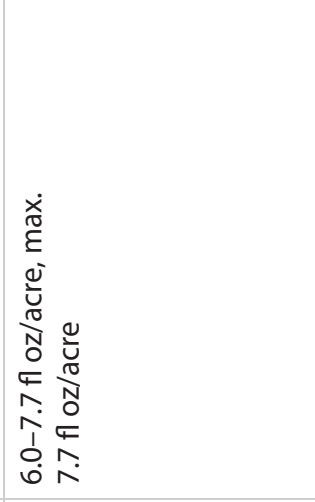 & 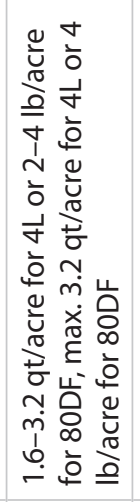 & 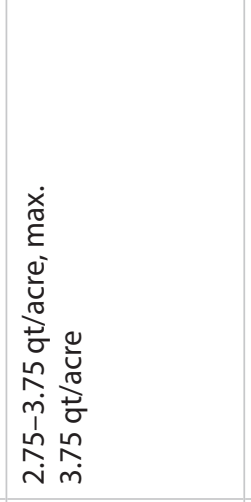 & 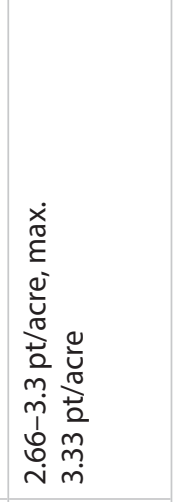 & & 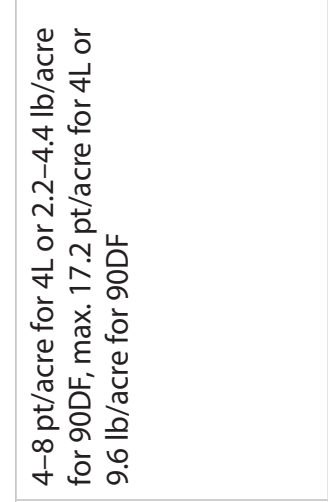 & 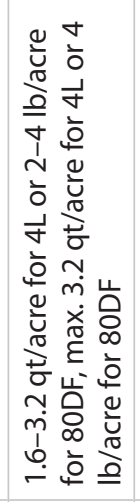 & 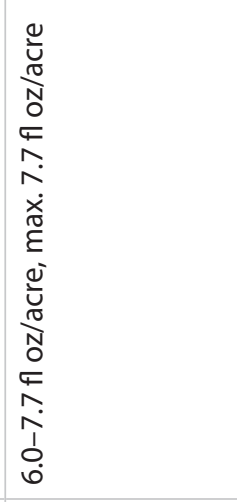 \\
\hline 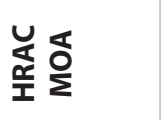 & $\grave{\sim}$ & in & $\begin{array}{l}+ \\
\stackrel{+}{n} \\
+\stackrel{\sim}{n} \\
\stackrel{n}{n}\end{array}$ & $\stackrel{+}{m}$ & & in & in & $\grave{\sim}$ \\
\hline 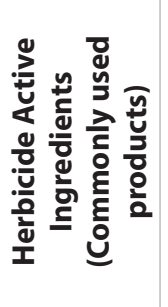 & 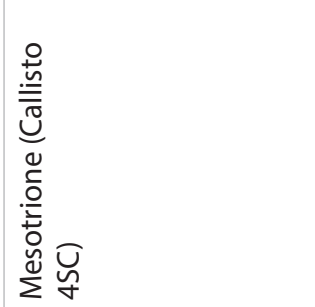 & 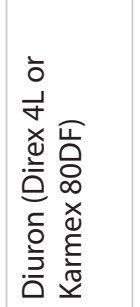 & 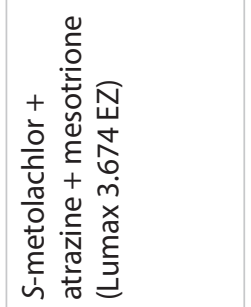 & 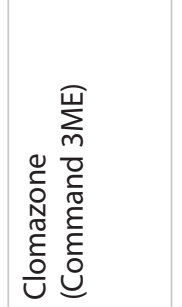 & & 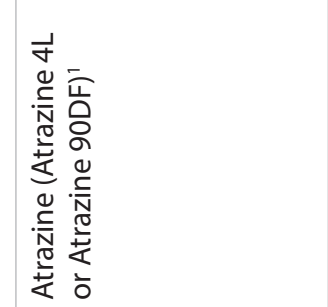 & 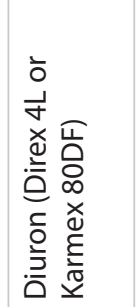 & 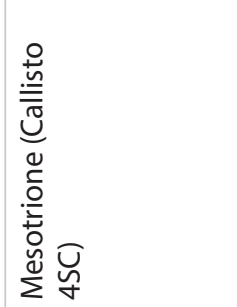 \\
\hline
\end{tabular}




\begin{tabular}{|c|c|c|c|c|c|c|c|c|c|c|}
\hline 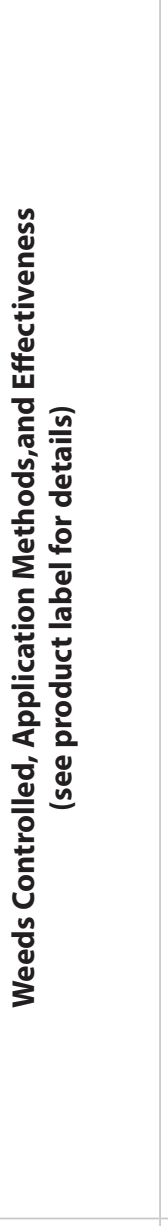 & 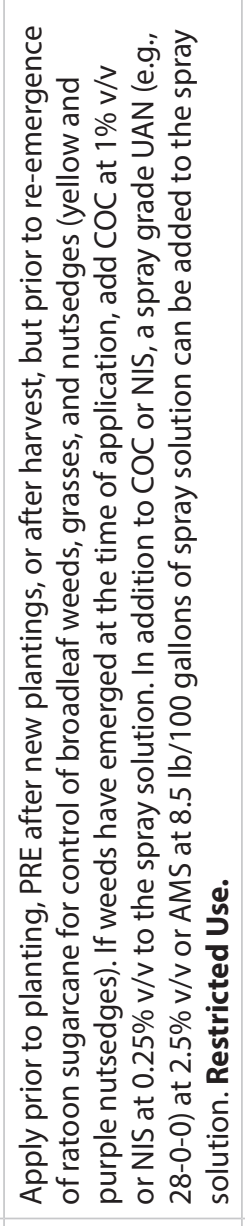 & 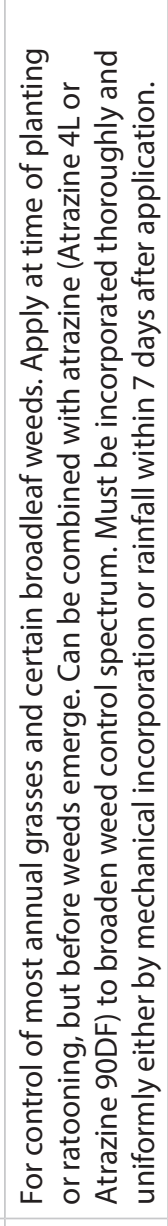 & 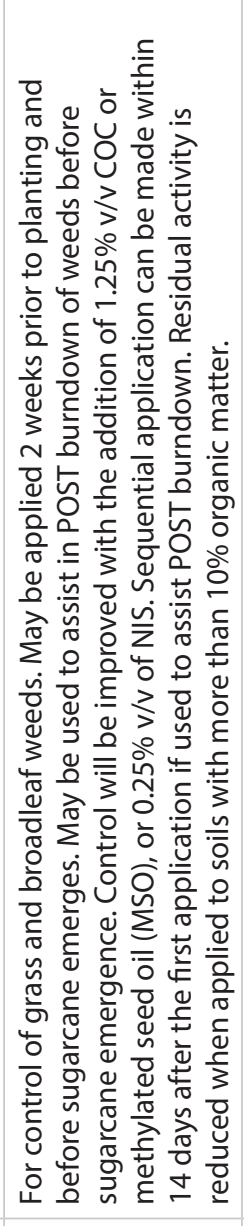 & 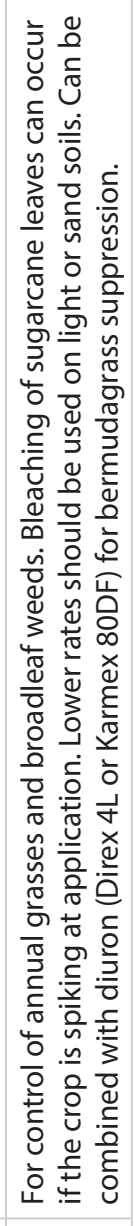 & $\mid$ & 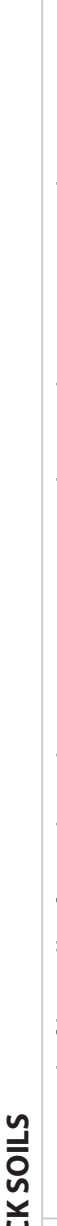 & 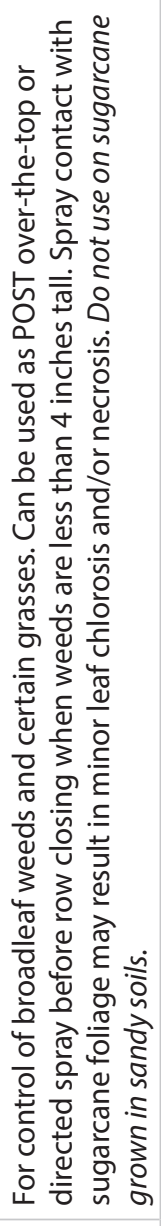 & 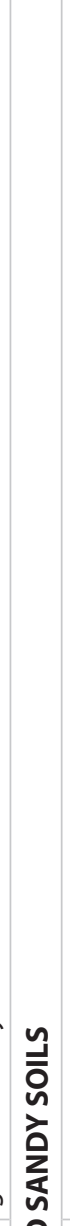 & 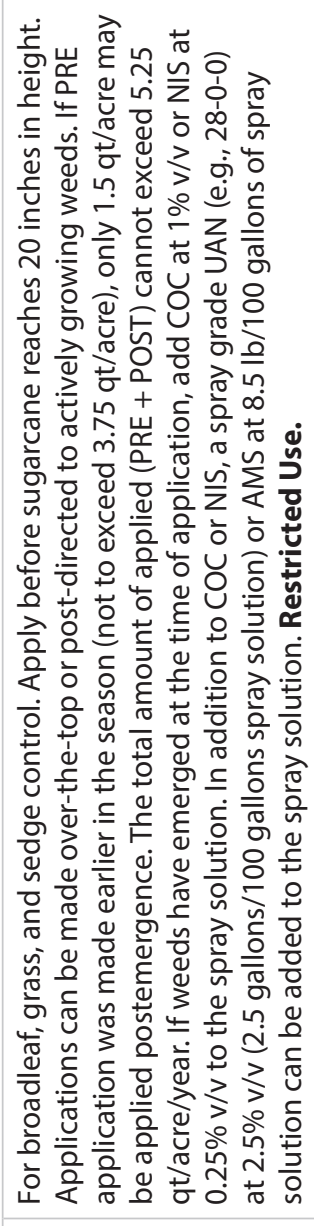 & 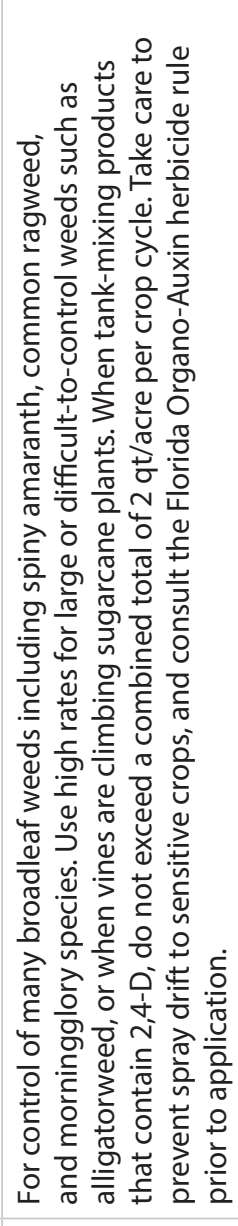 \\
\hline 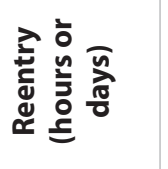 & 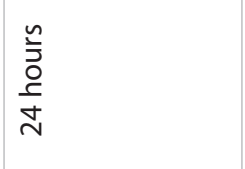 & 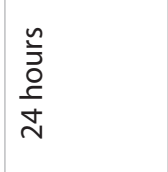 & 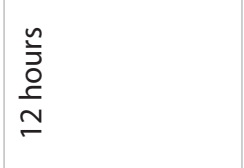 & 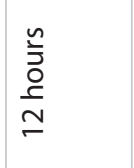 & Бั & $\vec{\Sigma}$ & 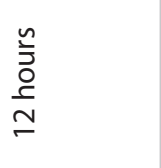 & 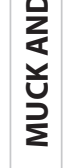 & 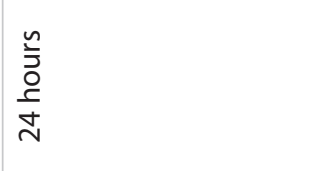 & 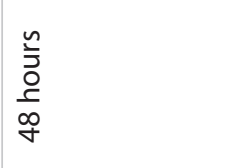 \\
\hline 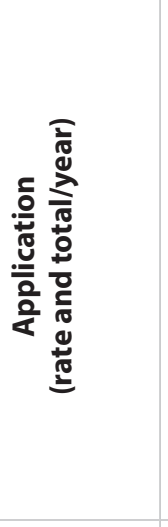 & 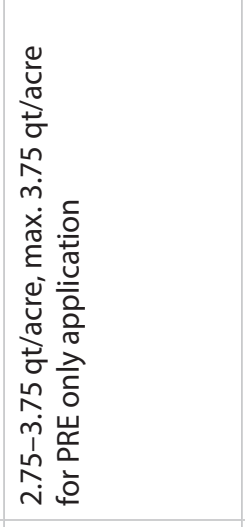 & 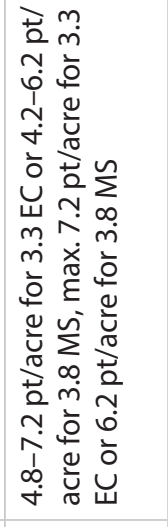 & 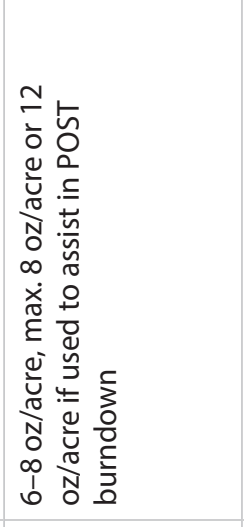 & 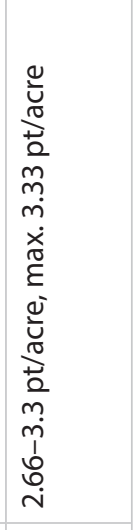 & & & 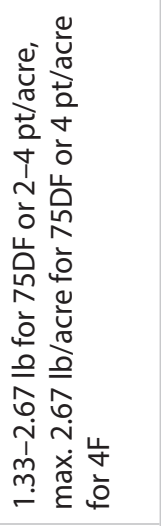 & & 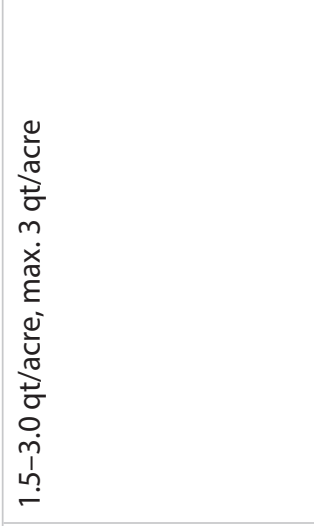 & 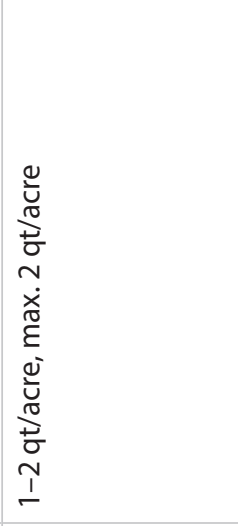 \\
\hline $\begin{array}{l}\text { U⿺尢丶 } \\
\text { 空 }\end{array}$ & 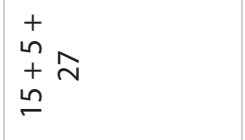 & $m$ & \pm & $\stackrel{+}{m}$ & & & in & & $\begin{array}{l}+ \\
\stackrel{+}{n} \\
+ \\
\stackrel{n}{L}\end{array}$ & $\nabla$ \\
\hline 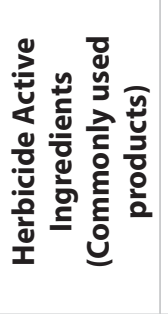 & 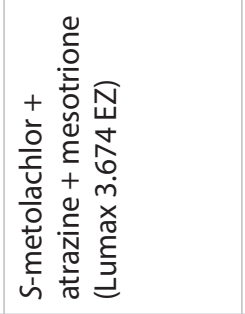 & 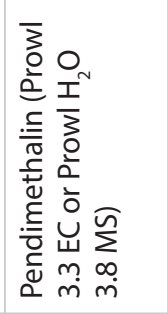 & 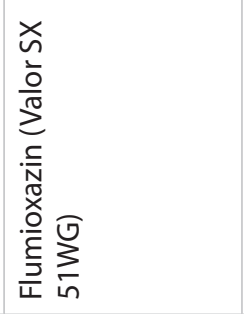 & 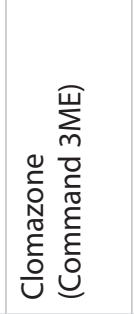 & & & 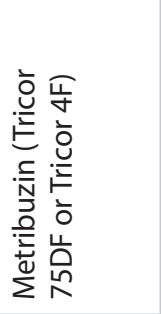 & & 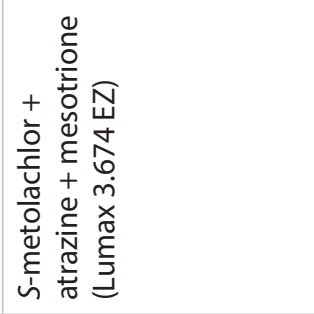 & 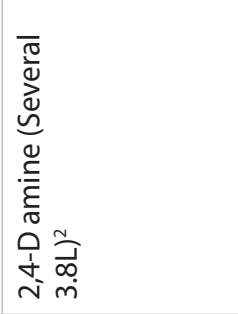 \\
\hline
\end{tabular}




\begin{tabular}{|c|c|c|c|c|c|}
\hline 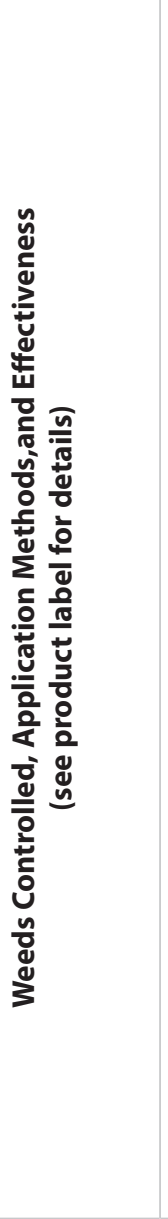 & 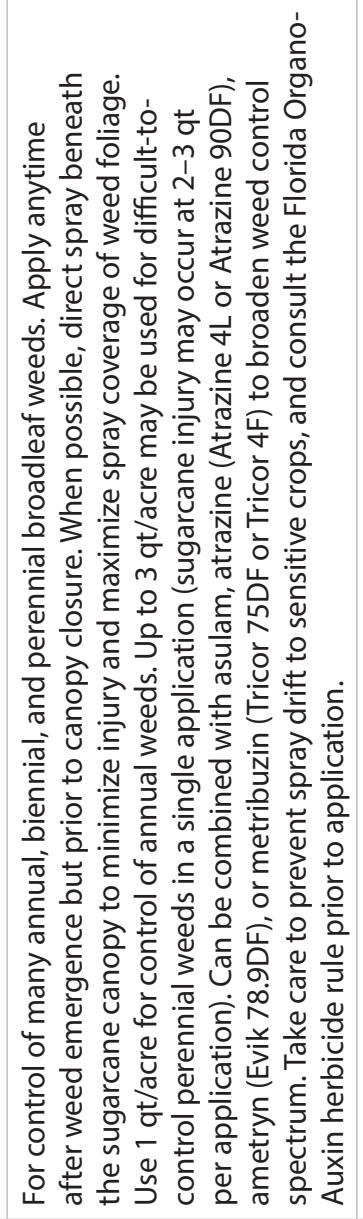 & 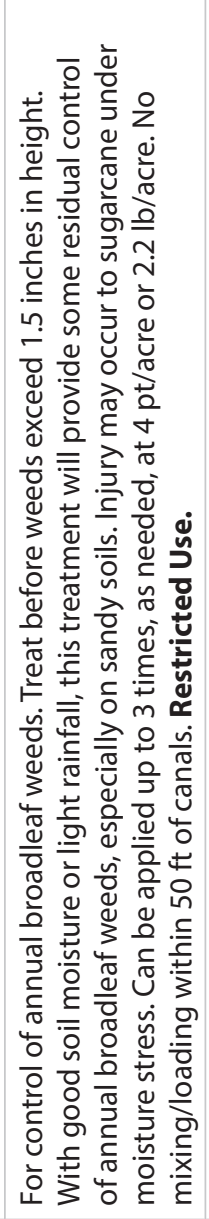 & 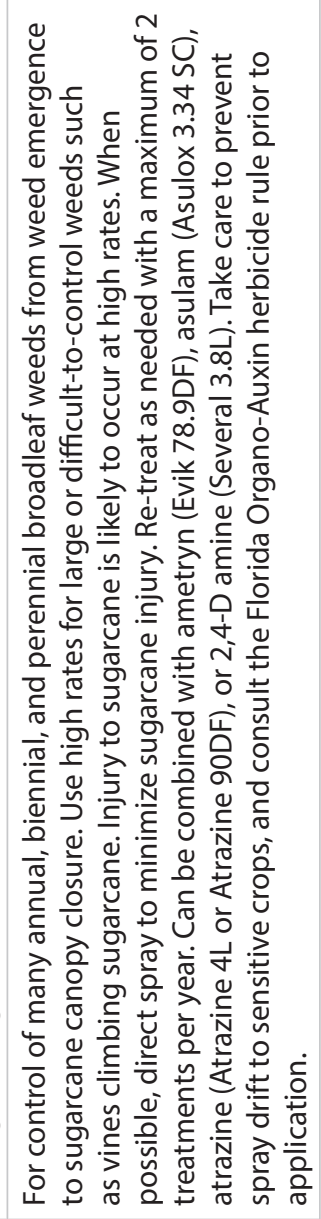 & 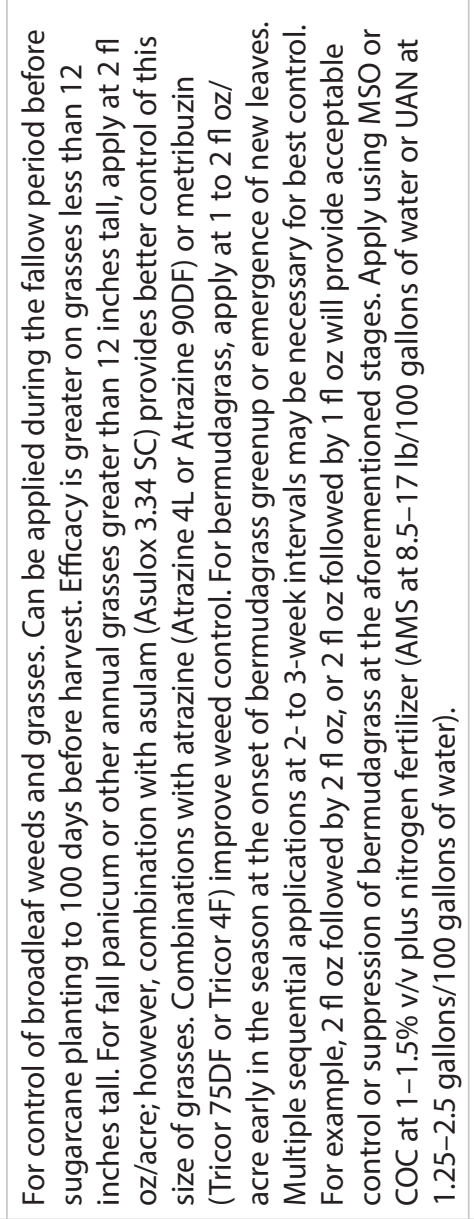 & 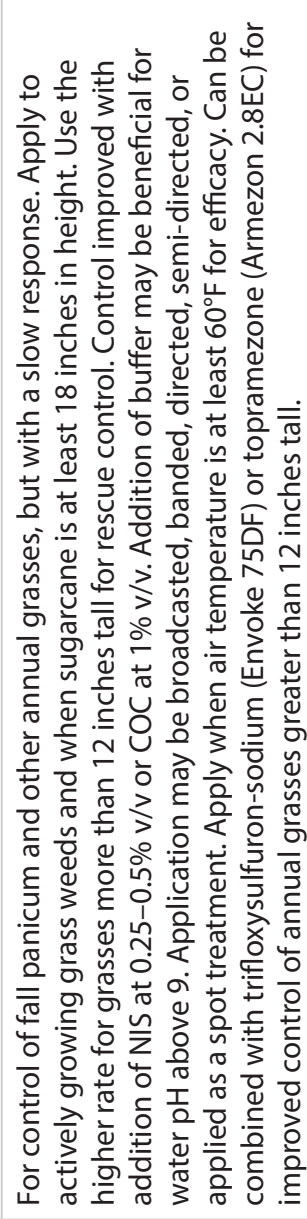 \\
\hline 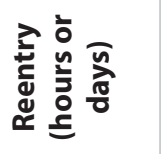 & $\begin{array}{l}\widetilde{n} \\
\stackrel{0}{0} \\
\frac{c}{\infty} \\
\stackrel{\alpha}{\sigma}\end{array}$ & 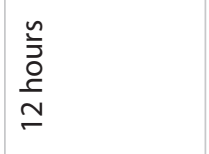 & 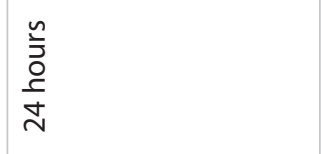 & 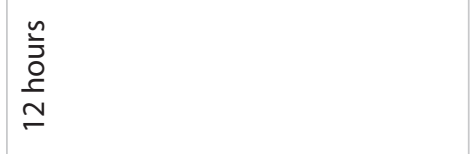 & 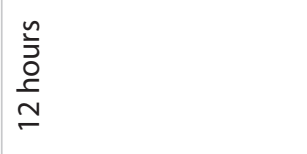 \\
\hline 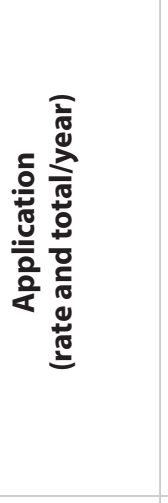 & 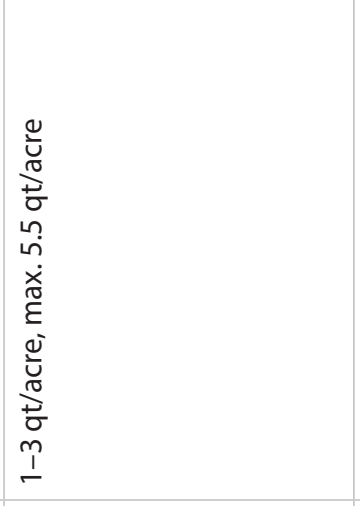 & 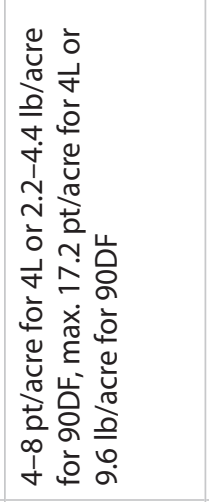 & 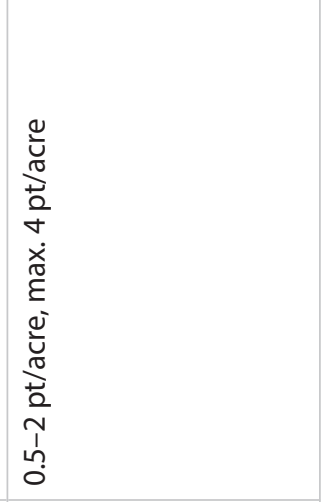 & 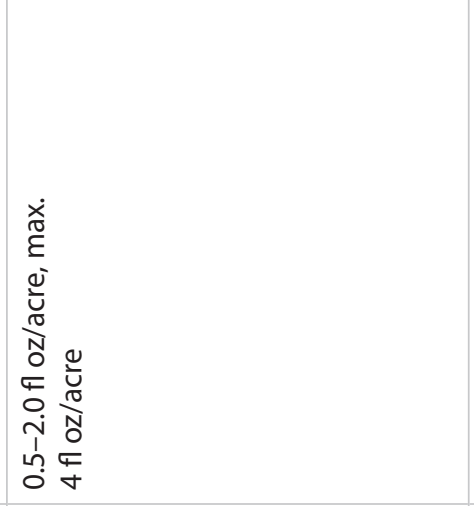 & 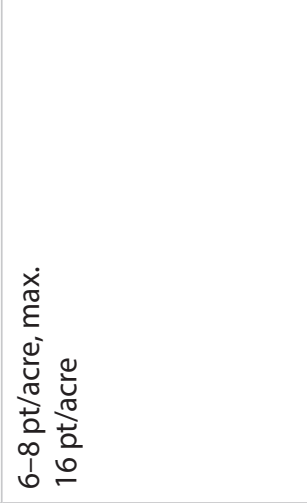 \\
\hline 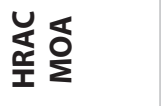 & $\sigma$ & in & $\nabla$ & $\grave{\sim}$ & $\stackrel{\infty}{\sim}$ \\
\hline 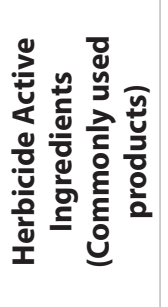 & 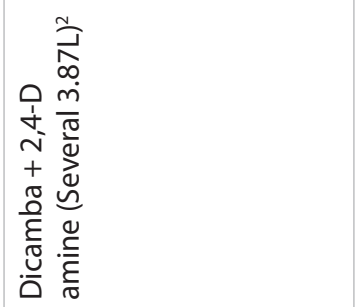 & 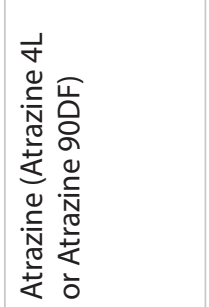 & 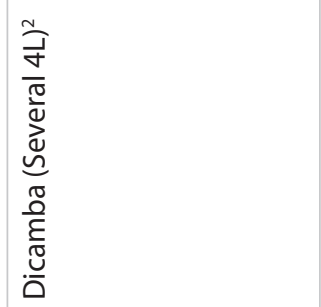 & 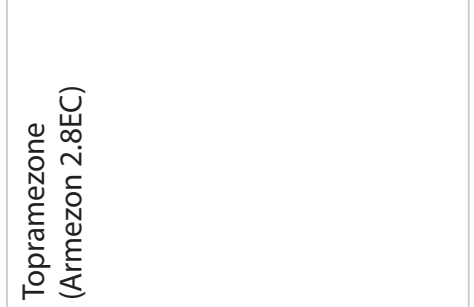 & 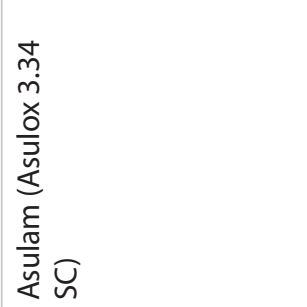 \\
\hline
\end{tabular}




\begin{tabular}{|c|c|c|c|c|c|}
\hline 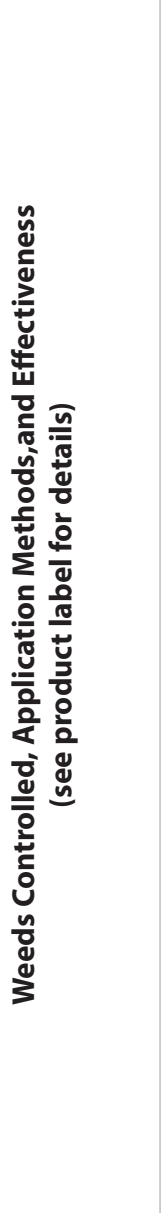 & 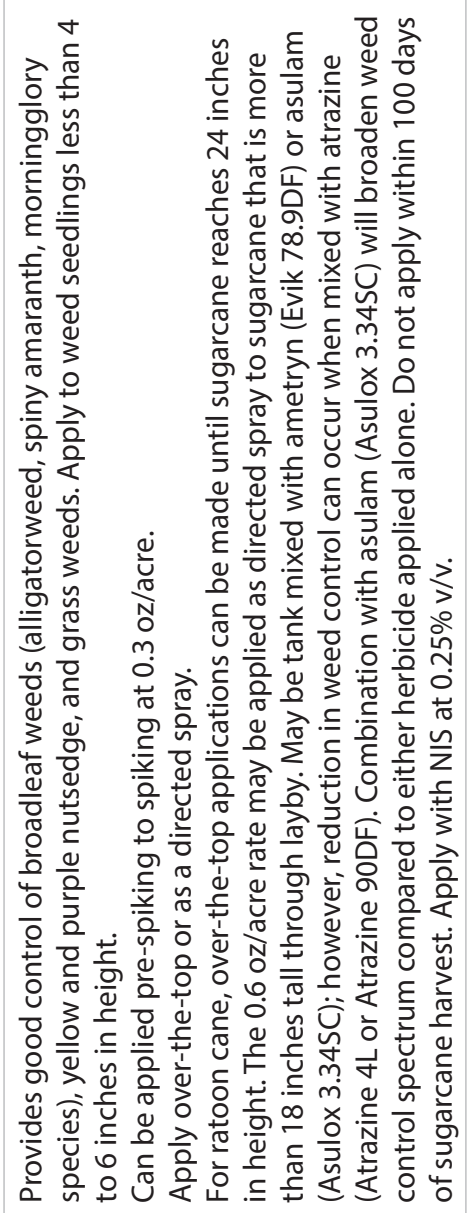 & 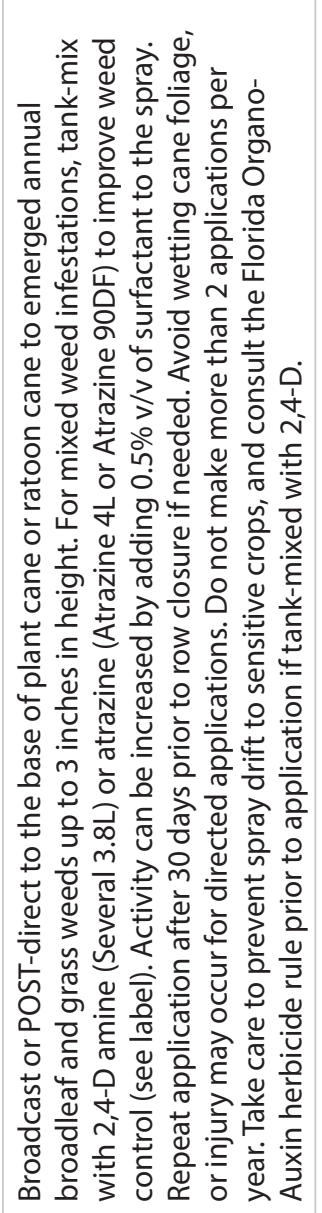 & 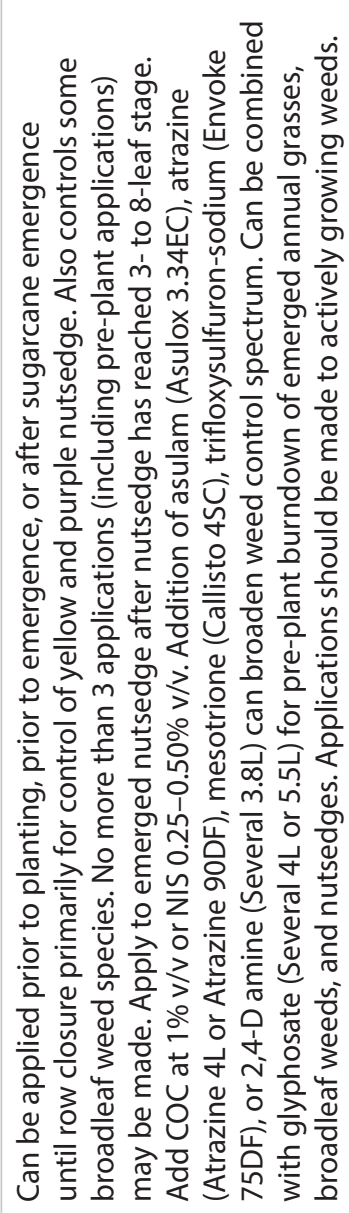 & 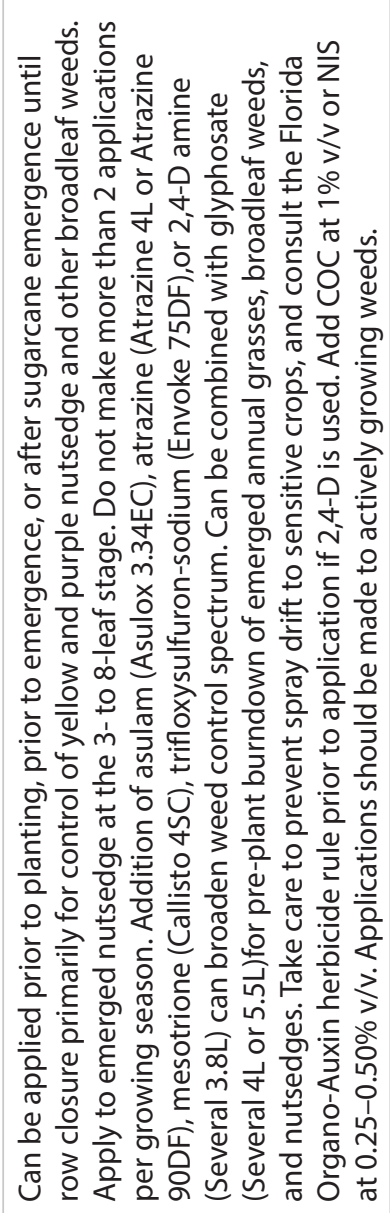 & 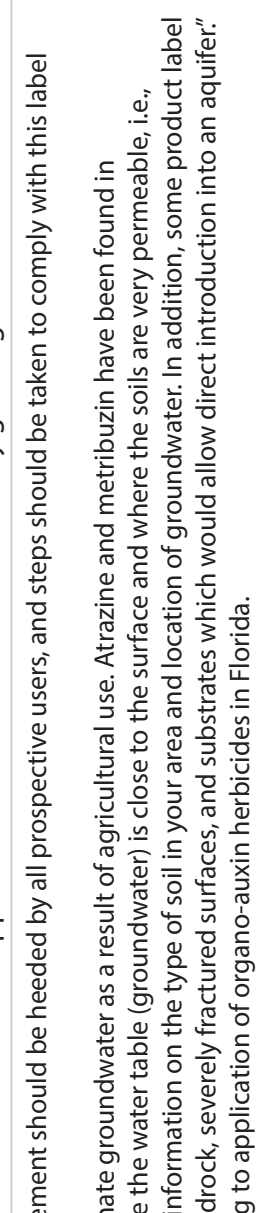 \\
\hline 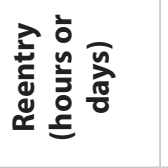 & 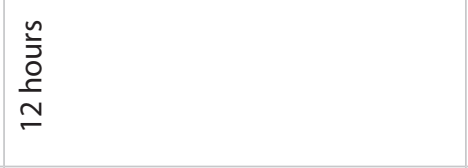 & 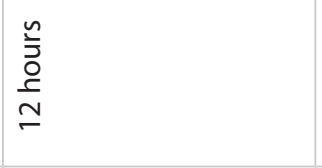 & 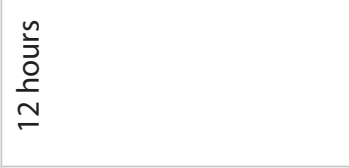 & 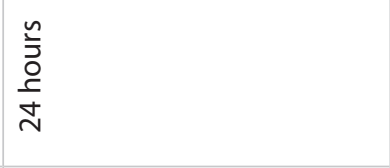 & 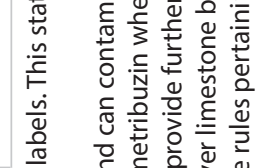 \\
\hline 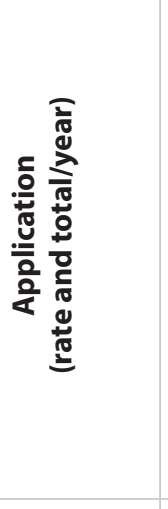 & 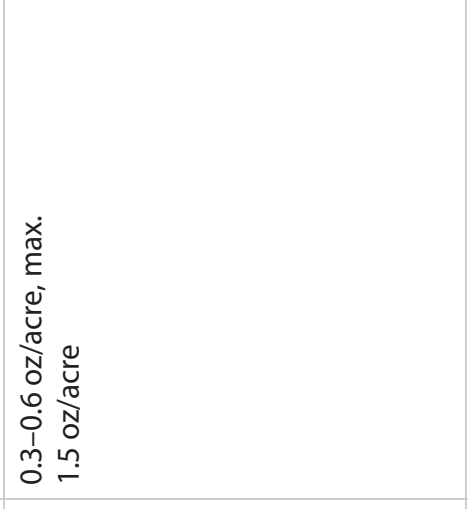 & 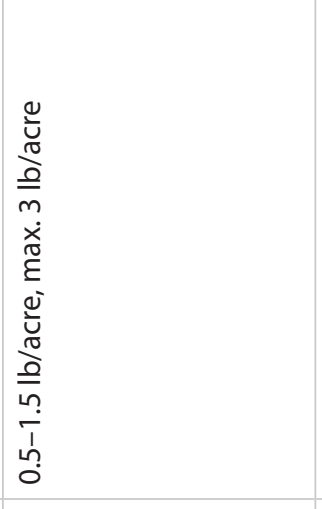 & 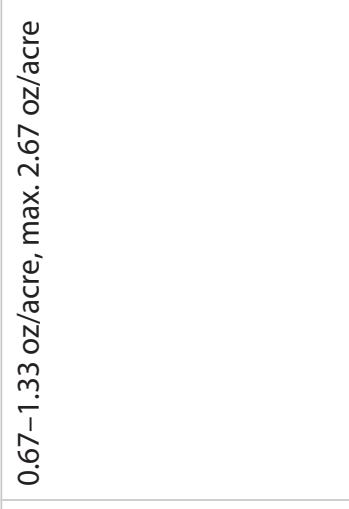 & 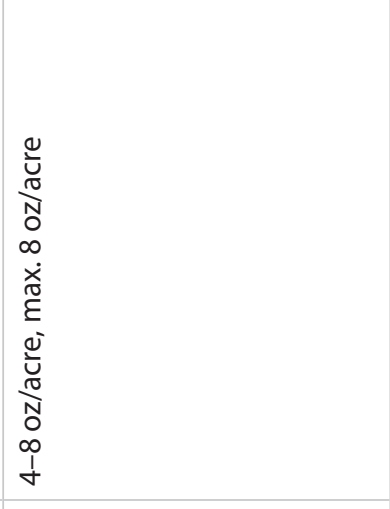 & 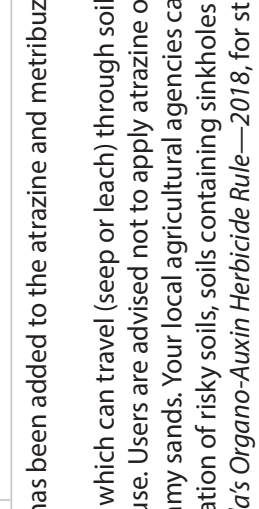 \\
\hline 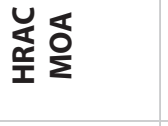 & $\sim$ & in & $\sim$ & $\stackrel{+}{\stackrel{+}{\sim}}$ & 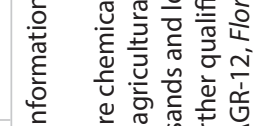 \\
\hline 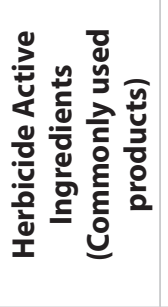 & 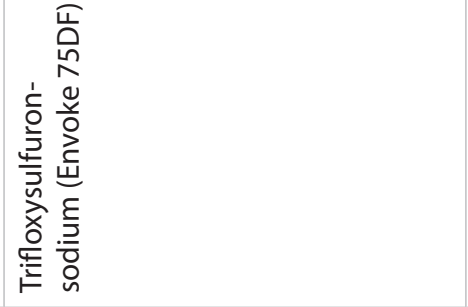 & 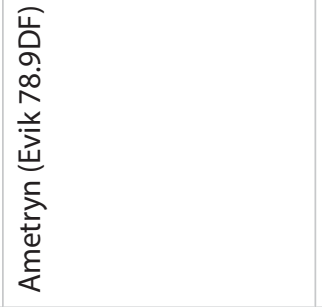 & 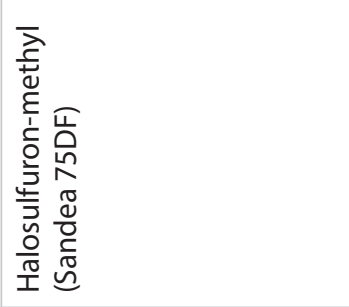 & 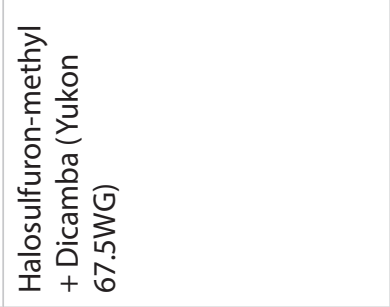 & 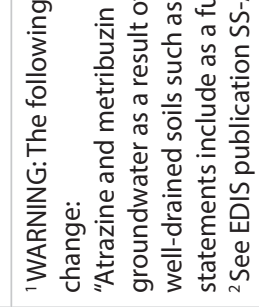 \\
\hline
\end{tabular}

